\title{
Faktor-Faktor yang Berhubungan dengan Pemberian ASI Eksklusif di Wilayah Kerja Puskesmas Baiturrahman
}

\author{
Factors Related to Giving Exclusive ASI Association in The Working Areas of \\ The Health Center of Baiturrahman
}

\author{
Asmaul Husna*1, ${ }^{*}$ aradilla Safitri ${ }^{2}$, Nuzulul Rahmi ${ }^{3}$ \\ ${ }^{1,2}$,Program Studi D-IV Kebidanan, Fakultas Ilmu Kesehatan, Universitas Ubudiyah Indonesia, Jl. Alue Naga Desa Tibang, \\ 23114, Banda Aceh, Indonesia \\ ${ }^{3}$ Program Studi D-III Kebidanan, Fakultas Ilmu Kesehatan, Universitas Ubudiyah Indonesia, Jl. Alue Naga Desa Tibang, \\ 23114, Banda Aceh, Indonesia \\ *Korespondensi Penulis: asmaulhusna@uui.ac.id
}

\begin{abstract}
Abstrak
Pemerintah telah menghimbau cakupan pemberian ASI Eksklusif masih rendah berdasarkan hasil Riset Kesehatan Dasar (Depkes RI) tahun 2010. Cakupan pemberian ASI Eksklusif pada bayi $0-5$ bulan $27.2 \%$ jika dilihat detail pemberian ASI pada bayi 5 bulan hanya $15.3 \%$. data Survey Demografi dan Kesehatan Indonesia (SDKI) menunjukkan tahun 2002 memberi ASI 40\% pada tahun 2007 turun menjadi 32\% (Riskesdas, 2010). Tujuan dari penelitian ini untuk Untuk mengetahui faktor-faktor yang berhubungan dengan pemberian ASI Eksklusif di Wilayah Kerja Puskesmas Baiturrahman. Penelitian ini dilakukan di wilayah kerja Puskesmas Baiturrahman pada bulan januari 2015. Sampel dalam penelitian ini adalah ibu-ibu yang memiliki bayi yang berumur 7-12 bulan dan berada di wilayah kerja Puskesmas Baiturrahman sebanyak 75 orang.. Hasil analisis bivariat di dapat bahwa tidak ada hubungan yang signifikan anatara pengetahuan dengan pemeberian ASI eksklusif dengan nilai $\mathrm{P}$ value $=0,240(\mathrm{p}<0.05)$ ada hubungan yang singnifikan antara dukungan suami dengan pemberian ASI eksklusif di Wilayah Kerja Puskesmas BaiturrahamanTahun 2017
\end{abstract}

Kata kunci : Pengetahuan, Dukungan Suami

\begin{abstract}
The government has called for the coverage of exclusive breastfeeding to be still low based on the results of the 2010 Basic Health Research (Depkes RI). Exclusive breastfeeding coverage for 0-5 months infants $27.2 \%$ when seen the details of breastfeeding in 5-month infants is only 15.3\%. Indonesia's Demographic and Health Survey data (IDHS) shows that 2002 giving 40\% ASI in 2007 fell to 32\% (Depkes RI, 2010). The purpose of this study is to determine the factors associated with exclusive breastfeeding in the Baiturrahman Health Center Working Area. This research was conducted in the Baiturrahman Community Health Center work area in January 2015. The samples in this study were mothers who had babies aged 7-12 months and were in the work area of Baiturrahman Health Center as many as 75 people. The results of the bivariate analysis were found that there was no significant relationship between knowledge and exclusive breastfeeding with $P$ value $=0.240(p<0.05)$ there is a significant relationship between husband's support and exclusive breastfeeding in Baiturrahaman Community Health Center Working Area 2017.
\end{abstract}

Keywords: Knowledge, Husband's Support 


\section{PENDAHULUAN}

ASI merupakan makanan yang paling cocok bagi bayi serta mempunyai nilai gizi yang paling tinggi dibandingkan dengan makanan bayi yang dibuat manusia ataupun susu hewan, seperti susu sapi. Air susu ibu mengandung lebih dari 200 unsur pokok antara lain zat putih telur, lemak, karbohidrat, vitamin, mineral, faktor pertumbuhan, hormon, enzim, zat kekebalan dan sel darah putih. Semua zat ini terdapat secara proporsional dan seimbang antara satu dengan yang lainnya (Moody, 2006).Menyusui didefinisikan sebagai pemberian makanan yangdihasilkan oleh ibu dan diberikan kepada anaknya melalui sistimreproduksi. Sedangkan menyusui adalah suatu proses alamiah. Berjuta-jutaibu diseluruh dunia berhasil menyusui bayinya tanpa pernahmembaca buku tentang ASI, bahkan ibu yang buta huruf pun dapatmenyusui bayinya dengan baik. Walaupun demikian dalam lingkungan kebudayaan kita saat ini melakukan hal yang alamiah tidaklah selalu mudah (Roesli, 2007).

ASI Eksklusif adalah intervensi yang paling efektif untuk mencegah kematian anak, namun menurut Survei Demografi Kesehatan tingkat pemberian ASI Eksklusif telah menurun selama decade terakhir. Hari ini, hanya sepertiga penduduk Indonesia secara eksklusif menyusui anak-anak mereka pada enam bulan pertama. Ada banyak hambatan untuk menyusui di Indonesia, termasuk anggota keluarga, dokter yang tidak mendukung. Beberapa juga ibu takut menyusui akan menyakitkan dan tidak praktis, tetapi salah satu kendala besar adalah kesalah pahaman istilah eksklusif' (UNICEF, 2012).

Pemerintah telah menghimbau cakupan pemberian ASI Eksklusif masih rendah berdasarkan hasil Riset Kesehatan Dasar (Riskesdas) tahun 2010. Cakupan pemberian ASI Eksklusif pada bayi 0-5 bulan 27.2\% jika dilihat detail pemberian ASI pada bayi 5 bulan hanya $15.3 \%$. data Survey Demografi dan Kesehatan Indonesia (SDKI) menunjukkan tahun 2002 memberi ASI 40\% pada tahun 2007 turun menjadi 32\% (Riskesdas, 2010).

Hasil Riset Kesehatan Dasar (Riskesdas) tahun 2010, cakupan pemberian ASI Eksklusif pada bayi 0-5 bulan 27,2\% jika dilihat detail pemberian ASI pada 5 bulan hanya 15,3\%. Data SDKI menunjukkan tahun 2002 pemberian ASI 40\% pada tahun 2007 turun menjadi 32\% (Depkes RI, 2010).

Berdasarkan studi pendahuluan diperoleh data dari dinas kesehatan Kabupaten Aceh Pidie jumlah bayi umur 0 - 6 bulan yaitu 5762 orang dan yang mendapat ASI Eksklusif 436 orang, dari data diatas pemberian ASI Eksklusif di Kota Bamda Aceh sebanyak 7,6 \% dari 
jumlahbayi, sementara di Kecamatan Delima dari 758 jumlah bayi, yang mendapat ASI Eksklusif sebanyak 205 bayi $(27 \%)$ disisi lain ASI Eksklusif terendah 0\% terdapat di Baiturrahman. Terlihat dari data di atas peneliti tertarik untuk mengetahui lebih lanjut tentang Faktor-faktor yang Berhubungan dengan Keberhasilan Pemberian ASI Eksklusif di Wilayah Kerja Puskesmas Baiturrahman.

\section{METODE PENELITIAN}

Penelitian ini merupakan penelitian survey analitik, dengan pendekatan crossectional yaitu penelitian untuk mengetahui faktor-faktor yang berhubungan dengan pemberian ASI Eksklusif di wilayah kerja Puskesmas Baiturrahman. Penelitian ini dilakukan di wilayah kerja Puskesmas Baiturrahman pada bulan januari 2017. Sampel dalam penelitian ini adalah ibu-ibu yang memiliki bayi yang berumur 7-12 bulan dan berada di wilayah kerja Puskesmas Baiturrahman sebanyak 75 orang.

Analisis univariat bertujuan untuk menjelaskan atau mendeskripsikan karakteristik setiap variabel penelitian. Pada analisis univariat peneliti hanya melihat distribusi frekuensi dan persentase setiap variabel yang diteliti yaitu pengetahuan, dukungan suami, budaya dengan pemberian ASI eksklusif. Analisis bivariat pada penelitian ini menggunakan uji statistik chi square, dengan batas kemaknaan $(\alpha=0,05)$ atau Confident Level (CL) $=95 \%$.

\section{HASIL DAN PEMBAHASAN}

Tabel 1. Hubungan Pengetahuan dengan Pemberian ASI eksklusif di Wilayah Kerja Puskesmas Baiturrahman

\begin{tabular}{|c|c|c|c|c|c|c|c|c|}
\hline \multirow[t]{3}{*}{ No } & \multirow[t]{3}{*}{ Pengetahuan } & \multicolumn{4}{|c|}{ Pemberian ASI eksklusif } & \multirow{2}{*}{\multicolumn{2}{|c|}{ Total }} & \multirow{3}{*}{$\begin{array}{c}P \\
\text { Value }\end{array}$} \\
\hline & & \multicolumn{2}{|c|}{ Ya } & \multicolumn{2}{|c|}{ Tidak } & & & \\
\hline & & $\mathbf{f}$ & $\%$ & $\mathbf{f}$ & $\%$ & n & $\%$ & \\
\hline 1 & Baik & 16 & 45.7 & 19 & 54.3 & 35 & 100 & \multirow{3}{*}{0,240} \\
\hline 2 & Cukup & 3 & 23.1 & 10 & 76.9 & 13 & 100 & \\
\hline 3 & Kurang & 8 & 29.6 & 19 & 70.4 & 19 & 100 & \\
\hline
\end{tabular}

Berdasarkan tabel 1 menunjukkan presentase responden dengan pengetahuan baik lebih banyak tidak memberikan ASI Eksklusif sebanyak 45.7 dibandingkan dengan responden pengetahuan kurang yaitu $29.6 \%$ dan responden pengetahuan cukup $23.1 \%$. Hasil uji statistic dengan menggunakan chi-square menunjukkan perbedaan persentase tersebut tidak bermakna 
yaitu dengan nilai $\mathrm{P}=0.240$ yaitu tidak ada hubungan pengetahuan dengan pemberian ASI Eksklusif di Wilayah KerjaPuskesmas Puskesmas Baiturrahman.

Tabel 2. Hubungan Dukungan Suami dengan Pemberian ASI Eksklusif di Wilayah Kerja Puskesmas Baiturrahman

\begin{tabular}{|c|c|c|c|c|c|c|c|c|}
\hline \multirow[t]{3}{*}{ No } & \multirow{3}{*}{$\begin{array}{l}\text { Dukungan } \\
\text { Suami }\end{array}$} & \multicolumn{4}{|c|}{ Pemberian ASI eksklusif } & \multirow{2}{*}{\multicolumn{2}{|c|}{ Total }} & \multirow{3}{*}{$\begin{array}{c}P \\
\text { Value }\end{array}$} \\
\hline & & \multicolumn{2}{|c|}{$\mathbf{Y a}$} & \multicolumn{2}{|c|}{ Tidak } & & & \\
\hline & & $\mathbf{f}$ & $\%$ & $\mathbf{f}$ & $\%$ & $\mathbf{n}$ & $\%$ & \\
\hline 1 & Mendukung & 20 & 52.6 & 18 & 47.4 & 38 & 100 & 0.005 \\
\hline 2 & $\begin{array}{l}\text { Tidak } \\
\text { Mendukung }\end{array}$ & 7 & 18.9 & 30 & 81.1 & 37 & 100 & \\
\hline
\end{tabular}

Berdasarkan tabel 2 menunjukkan persentase responden dengan mendapat dukungan suami lebih banyak memberikan ASI Eksklusif yaitu 52.6\% dari 38 responden yang tidak memperoleh dukungan suami yaitu 18.9\%. Hasil ujistatistik dengan menggunakan chi-square menunjukkan perbedaan persentase tersebut bermakna yaitu dengan nilai $\mathrm{P}=0.005$ yaitu ada hubungan dukungan suami dengan pemberian ASI Eksklusif di Wilayah Kerja Puskesmas Baiturrahman.

\section{Pembahasan}

1. Hubungan Pengetahuan Dengan Pemberian ASI Eksklusif

Berdasarkan hasil uji statistik (uji chi-square) diperoleh nilai $\mathrm{P}=0.240(\mathrm{P}>0.05)$. Artinya hipotesa alternatif peneliti ditolak yaitu tidakada hubungan yang bermakna antara Pengetahuan dengan Pemberian ASI Eksklusif di Wilayah KerjaPuskesmas BaiturrahmanTahun 2014. Hasil analisis hubungan antara PengetahuandenganPemberian ASI Eksklusif diperoleh dari 75 responden terdapat 48 responden di Wilayah KerjaPuskesmas Baiturrahman yang tidak memberikan ASI Eksklusif, dari 48 responden tersebut, 19 diantaranya memiliki pengetahuan baik (39.6\%), pengetahuan cukup 10 responden (20.8\%) dan pengetahuan kurang sebanyak 19 responden (39.6\%).

Hasil penelitian ini berbedadengan penelitian yang dilakukan Elinofia(2011) yang menunjukan terdapat hubungan yang bermakna antara pengetahuan dengan pemberian ASI Esklusif, dimana seluruh ibu (100\%) yang memiliki pengetahuan kurang, sedangkan pada 
ibu yang memiliki pengetahuan yang baik sebagian besar ibu $(74,4 \%)$ tersebut menyusui bayinya secara eksklusif. Hasil uji statistik menggunakan Chi-Squaredengan nilai p =0,01.

Hal ini pun tidaksejalan dengan pendapat Notoadmodjo (2005) yang mengungkapkan bahwa prilaku yang didasari oleh pengetahuan akan lebih langgeng dari pada prilaku yang tidak didasari pengetahuan. Pengetahuan ibu tentang ASI eksklusif dapat mempengaruhi ibu dalam memberikan ASI eksklusif. Semakin baik pengetahuan ibu tentang manfaat ASI eksklusif, maka seorang ibu akan memberikan ASI eksklusif pada anaknya, begitu juga sebaliknya.

Dari hasil penelitian juga menunjukkan bahwa pada ibu yang telah memiliki pengetahuan baiktentang ASI eksklusif masih terdapat yang tidak memberikan ASI secara eksklusif pada bayinya, yaitu 19 responden (54.3\%).

Hal ini Sejalan dengan pendapat Roesli (2006), seiring dengan perkembangan zaman, terjadi pula peningkatan ilmu pengetahuan dan teknologi yang demikian pesat. Selain itu, Roesli juga mengungkapkan bahwa fenomena kurangnya pemberian ASI eksklusif disebabkan oleh beberapa faktor diantaranya pengetahuan ibu yang kurang memadai tentang ASI eksklusif, beredarnya mitos yang kurang baik, serta kesibukkan ibu bekerja dan singkatnya cuti melahirkan, merupakan alasan yang diungkapkan oleh ibu yang tidak menyusui secara eksklusif.Hal ini terutama tercermin dari pengetahuan ibu tentang kandungan ASI, dimana pada umumnya ibu tidak mengetahui bahwa ASI mengandung semua zat yang dibutuhkan oleh tubuh bayi dan mengenai keunggulan ASI para ibu kurang mengetahui manfaat ASI bagi ibu, bayi dan negara. Ibu tidak mengetahui bahwa menyusui secara eksklusif dapat menjarangkan kehamilan, sementara manfaat ASI bagi bayi dapat meningkatkan hubungan kasih sayang antara ibu dan bayi dan bagi suatu negara dapat mengurangi devisa terhadap pembelian susu formula (Roesli, 2006).

Pengetahuan ibu dapat dipengaruhi oleh pengetahuan dan informasi yang didapat oleh ibu tentang ASI eksklusif. Pengetahuan atau kognitif merupakan hal yang sangat penting dalam membentuk tindakan seseorang, salah satunya kurang memadainya pengetahuan ibu tentang ASI eksklusif yang menjadikan penyebab atau masalah dalam peningkatan pemberian ASI eksklusif.

Asumsi peneliti, salah satu kondisi yang menyebabkan rendahnya pemberian ASI eksklusif adalah pengaruh budaya masyarakat yang menganggap ASI tidak ada sehingga 
apabila bayi menangis para orang tua menganggap bayi tersebut lapar sehingga memberikan makanan lain selain ASI. Meskipun pengetahuan mereka baik tentang ASI Eksklusif dimana penyuluhan kesehatan oleh tenaga kesehatan sering dilakukan namun mereka hanya dating sebagai formalitas sementara isi penyampaian penyuluhan diabaikan. Sebagai contoh pada saat penyuluhan mereka, motivasi mereka untuk turut menghadiri hanya untuk memperoleh makanan yang disediakan.

\section{Hubungan Sikap Ibu Dengan Kejadian Diare Pada Balita}

Berdasarkan hasil penelitian yang telah dilakukan menunjukkan bahwa dari 50 responden yang mengalami kejadian diare mayoritas sikap ibu positif yaitu sebanyak 21 responden (42\%), sedangkan dari 33 responden yang mengalami kejadian mayoritas sikap negatif yaitu sebanyak 23 responden $(69,7 \%)$. Berdasarkan hasil penelitian yang dilakukan oleh Nutrisiani (2010) yang berjudul faktor-faktor Hubungan Pengetahuan, Sikap Ibu Dengan Kejadian Diare Di Wilayah Kerja Puskesmas Langsa Kota, Desa Paya Bujuk , Blang Pase Tahun 2013" menunjukkan secara statistis bahwa terdapat hubungan antara sikap dengan kejadian diare pada bayi ( $\mathrm{p}$-value $=0,003)$.

Merupakan suatu hal yang dapat mempengaruhi perilaku seseorang terhadap sikap dan tindakannya, dalam hal ini menurut Notoadmodjo (2002) hal ini berpengaruh terhadap tindakan apa yang diambil oleh seseorang terhadap tindakan yang diambil oleh seorang ibu ketika dihadapi dengan masalah kesehatan balita. Dalam hal ini pengetahuan masyarakat (ibu rumah tangga yang memiliki balita) dapat memahami atau tidak penularan dan pencegahan penyakit diare pada balita, dengan adanya pengetahuan yang cukup bagi ibu diharapkan dapat meningkatkan derajat kesehatan terutama pada balita.

Ibu yang kurang baik sikap nya dalam penatalaksanaan diare tidak mendukung praktik ibu dalam penatalaksanaan diare. Sikap adalah merupakan reaksi atau respon seseorang yang masih tertutup terhadap suatu stimulus atau objek. Sikap secara nyata menunjukkan konotasi adanya kesesuaian reaksi terhadap stimulus tertentu yang dalam kehidupan sehari-hari merupakan reaksi yang bersifat emosional terhadap stimulus sosial. Sikap belum merupakan suatu tindakan atau aktivitas akan tetapi adalah merupakan predisposisi tindakan atau perilaku. Sikap itu masih merupakan reaksi tertutup bukan 
merupakan reaksi terhdap obyek di lingkungan tertentu sebagai suatu penghayatan terhadap obyek.

Sikap merupakan kecenderungan dalam subjek menerima atau menolak sesuatu obyek berdasarkan penilaian terhadap obyek itu sebagai obyek yang berharga sangat berperan dalam pengobatan diare karena merekalah yang biasanya melaksanakan upaya dehidrasi oral, memberikan makanan, mengenali dehidrasi dan pada waktunya mencari bantuan pengobatan serta pengobatan (Winkel, 2005).

Menurut asumsi peneliti,bahwadengan semakin positifnya sikap ibu menyebabkan semakin sedikit bayi yang mengalami kejadian diare dan dengan semakin negatifnya sikap ibu menyebabkan semakin banyak pula bayi yang mengalami kejadian diare. Hal ini dikarenakan dengan negatifnya sikap ibu menyebabkan ibu tidak memperdulikan cara pencegahan terjadinya diare pada bayinya.

\section{KESIMPULAN}

Berdasarkan hasil penelitian yang telah dilakukan maka penelitian dapat mengumpulkan hasil dari penenelitian sebagai berikut tidak ada hubungan yang signifikan anatara pengetahuan dengan pemeberian ASI eksklusif dengan nilai $\mathrm{P}$ value $=0,240(\mathrm{p}<0.05)$ ada hubungan yang singnifikan antara dukungan suami dengan pemberian ASI eksklusif di Wilayah Kerja Puskesmas BaiturrahamanTahun 2017.

\section{SARAN}

Diharapkan bagi peneliti selanjutnya yang berminat untuk membuat penelitian lebih lanjut dalam bentuk yang lebih kompleks dan rinci tentang kejadian diare pada bayi serta dengan jumlah sampel yang lebih banyak lagi. Diharapkanpada instansi kesehatan dapat memperbanyak lagi informasi tentang kejadian diare pada bayi sehingga dapat petugas kesehatan dapat memberikan penyuluhan kepada masyarakat terutama pada ibu tentang kejadian diare pada bayi sehingga ibu mengetahui cara pencegahan terjadinya diare pada bayi.

\section{DAFTAR PUSTAKA}

Ari Setiawan Saryono (2010). Metodologi Penelitian Kebidanan DIII, DIV, SI dan S2. Yogyakarta: Muha Medika.

Arora S, Junkin CM, Wherer J, Kuhn P. (2000). Mayor Factor Inluencing 
Breastfeeding Rates: Mother's Perception Of Father's Attitude And Milk Supply. Pediatrics. 106(5): e67.

Bedah ASI (2002). Jakarta: Salemba Medika.

Bunda (2008). "Pentingnya ASI Eksklsif". From : http://www.kelymom.com/new man/risk of formula.

Depkes RI (2010). "Buku Panduan Manajemen Laktasi". Suara Merdeka. From : www.Mcspotlinght.org.

Dewar Gwen, Ph.D (2008). Bayi Tidur masalah: sebuah panduan untuk orangtua yang berpikiran ilmiah. From : http://translate.googleusercontent.com/translate

Dian, 2000. Menyusui Bayi Anda. Jakarta : PT. Dian Rakyat.

Growwing Kids (2008), Parent-Directed Feeding, From http://www.GrowwingKids.org/.

Ganong, William F (2002). Buku Ajar Fisiologi Kebidanan. Jakarta: EGC.

Hector D, King L, Webb K, Heywood P. ( 2005 ). Factors Affecting Breastfeeding Practices: Applying A Conceptual Framework. NSW Public Health Bull.2005 16(3-4):52-55.

Hidayat A.Aziz Alimul (2006). Pengantar Kebutuhan Dasar Manusia. Buku 2. Jakarta: Salemba Medika.

Japardi Iskandar (2002). Ganguan tidur. Fakultas Kedokteran Bagian Bedah Universitas Sumatera Utara.

Kelly, P. (2007). Bayi Anda Tahun Pertama: Tips Bergambar Perawatan Bayi Tahap Demi Tahap. Jakarta : Arcan

Krityansari (2009). ASI Menyusui Dan Sadari. Jakarta: Salemba Medika.

Meedya S. Fahy. Kable A. (2010). Factors That Positively Influence Breastfeeding Duration To 6 Months: A Literature Review. Women and Birth. 2010, 23,135-145. 